\title{
ZARYS CHRYSTOLOGII PIETA SCHOONENBERGA
}

Do grona współczesnych teologów katolickich, którzy ze szczególnym zapałem usiłują wyjaśnić tajemnicę Jezusa Chrystusa, podając mniej lub więcej interesujące koncepcje chrystologiczne, należy bez wątpienia znany teolog holenderski Piet Schoonenberg, profesor dogmatyki na uniwersytecie w Nijmegen, główny inspirator głośnego w swoim czasie „katechizmu holenderskiego”. Uważając słusznie chrystologię za centralny problem teologiczny, za serce teologii, Schoonenberg poświęcił jej w ciągu ostatniego ćwierćwiecza szereg obszernych studiów ${ }^{1}$. Uwieńczeniem zaś większości z nich jest syntetyczne dzieło: Hij is een God van mensen (Hertogenbosch 1969), przetłumaczone od razu na język niemiecki (Ein Gott der Menschen, Einsiedeln 1969) i francuski (Il est le Dieu des hommes, Paris 1973).

Istotnym wątkiem wywodów chrystologicznych Schoonenberga jest jego krytyka orzeczenia Soboru Chalcedońskiego, które stanowi - jak wiadomo - podstawę chrystologii katolickiej. Dlatego warto na wstępie zwrócić uwagę na sposób patrzenia tego autora na orzeczenia dogmatyczne Kościoła oraz na jego założenia dotyczące interpretacji tych orzeczeń.

P. Schoonenberg określa dogmat, względnie orzeczenie dogmatyczne, jako ,wypowiedź wiary ujętą w formułę orzeczenia dogmatycznego, któ-

1 Do ważniejszych prac naukowych Schoonenberga należą: Het Geloof van ons doopsel, t. 2: Jezus de Christus, de Zoon Gods, t. 3: De Mensgeworden Zoon van God, Hertogembosich 1956-11958; Over de Godmens, „Bijdragem” 25 (11964) s. 166-186; De eenheid van Christus en de preexistentie van de Zoon, "Jaarboek" 1963/4; Christus zonder tweenheid? ,Tijldschirift voor Theologie" 6 (1966) s. 283306; Kenosis, "Concilium" 2 (1966) S. 24-33; Jezus Christus vandaag dezelfde, [w:] Geoloof bij kenterend getij. Roermond-Maaseik 1967, s. 1613-184: Das theologische Zentralproblem: Christologie, [w:] Antwort der Theologen zu Hauptproblemen der gegenwärtigen Kirche, Düsseldorf 1968, s. 29-61; Gods tegenwoordigheid in Christus: voorzetting van een gedachtenwisseling, ,Tijischrift voor Theologie" 9 (1969) s. 375-404; Monophysitic and dyophysitic languages about Christ, [w:] Wort und Wahrheit - Supplementary issue 1, Wien 1972, s. 154-166; Het avontuur der christologie, ,Tijdschrift voor Theologie" 12 (1972) s. 307-332; Ich glaube an Gott, ,Theologisiches Jahrbuch" 1974 s. 227-243. 
rą Magisterium Kościoła przedkłada dla obrony przed herezją" (GID s. 58) ${ }^{2}$. Dogmat nie jest - jego zdaniem - obwieszczeniem, jak kerygmat czy wyznanie wiary, lecz jest pouczeniem w okolicznościach kontrowersyjnych; nie stanowi on źródła czy strumienia Tradycji, lecz raczej łożysko, w którym ten strumień się porusza; stanowi szaniec obronny wiary (GID s. 59). Urząd nauczycielski pełni według Schoonenberga funkcję nadzorczą nad nauczaniem w Kościele. Potwierdza on wiarę Ludu Bożego, mając możność wnoszenia poprawek (GID s. 61). Orzeczenia dogmatyczne są - holenderski teolog podkreśla to bardzo mocno - naznaczone zawsze piętnem historyczności, czyli różnych uwarunkowań i okoliczności historycznych. Dlatego też wymagają one odpowiedniej interpretacji, która wprowadzałaby pomost między sytuacją, w jakiej dane orzeczenia powstały, a nową, odmienną sytuacją współczesną (GID s. 62).

Interpretacja orzeczeń dogmatycznych jest zawsze ich pewnym tłumaczeniem. Polega ono na oddaniu treści pierwotnego tekstu nowoczesnym językiem (GID s. 97). Interpretatora tekstów dogmatycznych obowiązują te same zasady, co tłumacza jakichkolwiek tekstów wymagających tłumaczenia. Musi on wiedzieć dokładnie, co zawiera tekst tłumaczony, i musi dokładnie to samo wyrazić innym językiem, odpowiadającym aktualnemu sposobowi myślenia i przedstawiania, czyli językiem o nowoczesnych przesłankach filozoficznych, kulturowych, naukowych i przednaukowych (GID s. 63). „Prawdziwa interpretacja jest — zdaniem Schoonenberga - planowym i twórczym nadawaniem sensu określonym tekstom" (GID s. 102). Ponieważ dzisiejszy sposób myślenia, przynajmniej myślenia zachodniego, jest sekularyzacyjny, dlatego tłumaczenie dogmatów w dzisiejszej sytuacji ,,jest zawsze w pewnym określonym stopniu tłumaczeniem na myślenie sekularyzacyjne" (GID s. 97). Powtarzanie i branie dosłownie formuł dogmatycznych z przeszłości może powodować niewłaściwe czy wprost fałszywe rozumienie nauki wiary.

W kwestii nieomylności i niezmienności orzeczeń dogmatycznych, wiążącej się ze sprawą ich interpretacji, autor zajmuje swoiste stanowisko. Uznaje on w zasadzie pewną nieomylność całego Kościoła, a w nim Urzędu Nauczycielskiego dzięki asystencji Ducha Swiętego, ale ta nieomylność jest ograniczona i względna. „Nieomylność stworzenia jest sama w sobie omylna, ponieważ ciągle się jeszcze ono rozwija" (GID s. 94). „Duch Swięty prowadzi Kościół poprzez poszukiwania i próby, a stąd poprzez niewłaściwe poglądy, przez całe i połowiczne prawdy i dlatego także przez połowiczne i całkowite błędy. Jest On obecny nie

2 Skrótem umieszczonym 'w nawiasie oznaczam tytuł artykułu $\mathbb{P}$. Schoonenberga: Geschichtlichkeit und Interpretation des Dogmas, [w:] Die Interpretation des Dogmas, Düslseldorf 1969 , s. $58-1110$. 
tylko w dojrzałych rozpoznaniach wiary, lecz także w poszukiwaniu i dyskusji" (GID s. 96). Toteż orzeczenia dogmatyczne są tylko relatywnie nieomylne, a mianowicie $\mathrm{w}$ relacji do całości i to całości stającej się (GID s. 94). „Bezbłędność albo nieomylność dogmatów dana jest w ich powolnym budowaniu rosnącej interpretacji wiary [...] Nieomylność pojedynczych dogmatów leży w nich samych, o ile przyjęte są do całości [...]. Również omylne i wręcz błędne orzeczenia mogą mieć miejsce" (GID s. 95). Orzeczenia dogmatyczne mogą więc i powinny - zdaniem naszego autora - podlegać krytyce. Mogą one też ulegać zmianom; „niezmienność ich implikuje istotną zmienność". Istnieje możność, a w danych okolicznościach nawet konieczność reinterpretacji wszystkich dogmatów (GID s. 96, 102).

Wychodząc $\mathrm{z}$ powyższych założeń, przeprowadza Schoonenberg krytykę oraz radykalną reinterpretację orzeczenia chalcedońskiego. Domaga się ono - jego zdaniem - takiej reinterpretacji, ponieważ brane dosłownie nie odpowiada współczesnej sytuacji historyczno-kulturowej i mentalności dzisiejszych ludzi. Definicja chalcedońska powstała w innej niż obecna sytuacji historyczno-kulturowej. Zdeterminowana była ona przez pojęcia filozoficzne średniego platonizmu i przez kontrowersje występujące w antagonizujących ze sobą szkołach teologicznych: aleksandryjskiej i antiocheńskiej. Sobór Chalcedoński chciał pogodzić ze sobą obie koncepcje chrystologiczne. Chciał dopiąc tego celu, wprowadzając model dwóch natur i jednej osoby w Chrystusie, jako model zabezpieczający zarówno przed nestorianizmem, jak i przed monofizytyzmem (DH s. 22) ${ }^{3}$. Jednakże model ten nie jest dzisiaj do przyjęcia w dosłownym jego znaczeniu. Orzeczenie chalcedońskie winno być na nowo przetłumaczone, ponieważ nie może ono dzisiaj wyrazić tego, co chciało i mogło wytłumaczyć niegdyś. Autor chce więc przebadać chrystologię Chalcedonu i nie tylko wysnuć z niej nowe wnioski, lecz także odnowić więź jednoczącą chalcedoński dogmat z Tradycją starszą, z chrystologią Nowego Testamentu, z kerygmatem stanowiącym podstawę pierwotnej Tradycji (DH s. 14). Teolog holenderski chce dopełnić i ponrawić tradycyjny model chrystologiczny, aby był ,mniej mityczny i mniej religijny, a więcej ludzki” (DH s. 34).

Do zarzutów, jakie wytacza przeciwko formule chalcedońskiej, względnie dosłownemu braniu jej obecnie, należy najpierw zarzut co do ter-

${ }^{3}$ Skrót umieszczony w nawiasie odnosi się do francuskiego przokładu głównego dziela P. Schoonenberga: Il est le Dieu des hommes, Paris 19713. 
minu „natura”. Termin ten bowiem ma w nowoczesnym słownictwie inne znaczenie aniżeli miał je $\mathrm{w}$ okresie patrystycznym. Sobór Chalcedoński chciał przez formułę dwóch natur wyrazić myśl o pełnym realizmie bytu zarazem ludzkiego, jak i boskiego w Chrystusie, zdając się uznawać synonimiczność terminów "natura" i ,istota". W nowoczesnym zaś słownictwie wyraz "natura” ma znaczenie przeciwstawne do wyrazu ,osoba" (DH s. 29). Zastrzeżenie budzi też - zdaniem Schoonenberga stawianie obok siebie $\mathrm{w}$ jednym rzędzie i dodawanie do siebie natury boskiej i ludzkiej. Jeśliby to miało wyrażać, że pojęcie natury względnie istoty aplikuje się jednoznacznie do pierwiastka boskiego i ludzkiego w Chrystusie, to model dwóch natur prowadziłby do wielkich błędów (DH s. 29).

Dalszy zarzut Schoonenberga w odniesieniu do formuły chalcedońskiej dotyczy jej ,esencjalizmu i braku związku z soteriologią. Rozprawianie bowiem o naturach w Chrystusie nie pozostaje w żadnym stosun$\mathrm{ku}$ do naszej egzystencji, do zbawienia (DH s. 30). Brakiem w modelu chalcedońskim jest też to, że nie mówi on niczego o miejscu Jezusa w historii zbawienia ani o historii zbawienia samego Jezusa, o następstwie etapów zbawienia w sercu Jego bosko-ludzkiej egzystencji; nie wzmiankuje o różnicy zachodzącej między etapem Jego życia ziemskiego a etapem życia chwalebnego, o których to etapach Pismo św. mówi wyraźnie w liście do Filipian 2, 6-11 (DH s. 32).

Nie widać wreszcie, co w świetle formuły chalcedońskiej można by powiedzieć o synostwie Bożym Jezusa jako człowieka: czy jako taki jest On Synem Bożym z natury, czy też przez łaskę? Czy osobowość ludzka Jezusa została przejęta $\mathrm{w}$ osobę Słowa i wobec tego jest On jako człowiek pozbawiony swej ludzkiej osobowości? Czy raczej Jego ludzka osobowość stanowi na płaszczyźnie ludzkiej centrum aktów, decyzji, samoświadomości i tak istnieje też obok boskiej osoby? Czy model chalcedoński prowadzi do Logosu przebranego za człowieka, czy też do Chrystusa podzielonego? (DH s. 33). W związku z zarzutami i trudnościami, jakie - zdaniem holenderskiego teologa - nasuwają się przy interpretacji orzeczenia chalcedońskiego, przeprowadził on swoistą „przeróbkę" modelu chalcedońskiego.

\section{III}

Swoją chrystologię określa Schoonenberg jako (a) chrystologię bez dwoistości, (b) chrystologię obecności Boga, (c) chrystologię transcendencji ludzkiej i znaczenia zbawczego (DH s. 70). Kieruje się w tej koncepcji „podstawową intuicją”, a mianowicie, że „Bóg nie czyni konkurencji, 
Bóg nie alienuje. Nie pozbawia On nas naszego człowieczeństwa, lecz czyni nas bardziej ludzkimi przez swoje Słowo uczynione człowiekiem [...] nasze ubóstwienie jest naszą humanizacją" (DH s. 9).

Wykluczając dwoistość w Jezusie Chrystusie, nie ma nasz autor na myśli dwoistości i złożoności w Jego człowieczeństwie, lecz dwoistość wyrażoną przez chalcedoński model dwóch natur: dwoistość pierwiastka boskiego i ludzkiego, czyli jakby dwoistość osób w Jezusie. Wszyscy są zgodni co do tego, że Jezus Chrystus jest kimś jednym, jedną osobą (DH s. 37 n.). Według tradycyjnej chrystologii tą jedną osobą jest boska osoba Słowa. Tak tłumaczyli orzeczenie chalcedońskie (w duchu teologii aleksandryjskiej) neochalcedończycy. Sam Sobór Chalcedoński nie określił jedynej osoby w Chrystusie jako preegzystującej osoby boskiej, lecz raczej zdawał się uważać jedyną osobę za rezultat dwóch natur (DH s. 23,50$)$. Nie należy więc rozumieć orzeczenia chalcedońskiego w znaczeniu jedynej w Chrystusie boskiej, preegzystującej osoby, która przyjęła do swego uczestnictwa naturę ludzką Jezusa, nie posiadającą własnej osobowości. Zgodnie $\mathrm{z}$ danymi Nowego Testamentu - tak sądzi Schoonenberg - należy przyjąć, że jedyna osoba w Chrystusie jest osobą ludzką. Najbardziej centralnym w Jezusie człowieku jest to, że jest On osobą ludzką o ludzkim psychologicznym i ontologicznym ośrodku świadomości i decyzji. Rozumienie formuły chalcedońskiej w sensie jednej boskiej preegzystującej osoby prowadziłoby do zaprzeczenia integralności człowieczeństwa Jezusowego. „Bo cóż to za człowiek - pyta Schoonenberg - jeśli nie jest on osobą, jeśli nie bierze on, jako osoba, w swoje własne dłonie swego przeznaczenia i swego bytu poprzez dobrowolne decyzje" (DH s. 48). Nie można mówić na serio o kompensacji osobowości ludzkiej Jezusa przez przyjęcie Jego natury ludzkiej. Teolog holenderski występuje stanowczo przeciwko poglądowi o enhipostazie natury ludzkiej Jezusa w boskiej osobie Słowa. „W naszej koncepcji powiada - to nie natura ludzka jest enhipostatyczna w osobie boskiej, lecz natura boska jest enhipostatyczna w osobie ludzkiej [...]. Enhipostaza Słowa czy Syna jedynego w osobie ludzkiej Jezusa jest bardziej do przyjęcia niż koncepcja odwrotna, ogólnie przyjmowana" (DH s. 64). Za swoją teorię uważa Schoonenberg teorię enhipostazy Słowa Boga w Jezusie Chrystusie, czyli przyjmuje on swoistego rodzaju unię hipostatyczną o odwrotnym charakterze i skutku aniżeli przyjmuje to tradycyjna nauka katolicka.

Jest wszakże rzeczą charakterystyczną, że autor nasz wprawdzie zaprzecza Wcieleniu Słowa osobowego, preegzystującego oraz enhipostazy w Nim natury ludzkiej Jezusa, to jednak mówi o boskiej osobie Jezusa Chrystusa. Według jego opinii, Chrystus jest zarazem osobą boską i ludz- 
ką, ale nie przez dodanie do siebie osób, ani też drogą dialogu czy przymierza, lecz przez to, że jedna i ta sama osoba jest boską i ludzką, względnie bosko-ludzką. My bowiem nie poznajemy boskiej osoby Jezusa inaczej jak tylko ,wedle człowieka”, którym jest Jezus Chrystus w całej pełni. „Słowo w Jezusie jest osobą przez fakt, że jest On człowiekiem i jest On boską osobą przez fakt, że jest On osobą ludzką" (DH s. 63).

By uzasadnić tę swoją paradoksalną tezę, powołuje się Schoonenberg na dane biblijne, mówiące o odwieczności Jezusa, a które - jego zdaniem - chcą wyrazić to, „czym Chrystus jest obecnie dla nas i co obecnie znaczy On dla nas [...]. Wszystko, co stwierdzono o Jego boskości i o Jego preegzystencji, stwierdzono w odniesieniu do [konkretnej postaci historycznej] Jezusa Chrystusa [...] Czy Słowo istniało już w Bogu przed Wcieleniem, daremnie się nam pytać. Dopiero właściwie Orygenes, pozostający pod wpływem filozofii platońskiej, opowiedział się za preegzystującym, osobowym Słowem Bożym. I ta jego opinia przyjęła się na stałe w nauce katolickiej" (DH s. 57, 59).

Jak to jednak należy rozumieć, że jedyna osoba ludzka w Chrystusie jest zarazem osobą boską, względnie jest ona osobą bosko-ludzką, a Chrystus człowiek jest równocześnie Synem Bożym? Co decyduje o tym fakcie? Otóż według naszego teologa decyduje o tym totalna, absolutnie suwerenna obecność Boga w Jezusie Chrystusie, od samego Jego początku. Zgodnie ze słowami św. Pawła (Kol. 2, 9) pełnia boskości weszła w Jezusa od samego początku i zamieszkała w Nim cieleśnie, wcieliła się w Niego. Przeniknęła też na wskroś Jego działalność, tak że wbrew orzeczeniu Soboru Konstantynopolitańskiego III nie ma w Chrystusie dwojakiej woli i dwojakiego działania, lecz tylko jedna wola i jedno działanie bosko-ludzkie. Błędem byłoby wyróżnianie w Chrystusie sfery czysto ludzkiej działalności (DH s. 71-75). „Synostwo Boże Jezusa Chrystusa jest doprowadzeniem Jego bycia czlowiekiem do ostatecznej pełni" (DH s. 9). O synostwie Bożym i świętości można mówić tylko jako o pełnej humanizacji, a tym samym jako o ludzkiej transcendencji Jezusa Chrystusa (DH s. 74 n.).

IV

Dzięki totalnej, absolutnie suwerennej obecności Boga w Jezusie człowieku Jego człowieczeństwo jest, według Schoonenberga, transcendentne $\mathrm{w}$ stosunku do człowieczeństwa innych ludzi. „Ludzka transcendencja Jezusa znamionuje całą Jego egzystencję. Urzeczywistnia się ona zarów- 
no w Jego historii ziemskiej jak i w chwale [...] Transcendencja Chrystusa zakotwiczona jest w pełni człowieczeństwa" (DH s. 78).

Mając na uwadze tę ludzką transcendencję, trudno autorowi rozstrzygnąć kwestię, czy różnica między Jezusem a innymi ludźmi jest istotowa, czy tylko przypadłościowa, czy absolutna, czy tylko relatywna. Odrzuca on te określenia jako nieadekwatne, a opowiada się za terminem „eschatologiczny”. Jezus Chrystus - powiada Schoonenberg — ,jest eschatologicznym szczytem zbawczej działalności Boga, a stąd i naszej historii zbawienia" (DH s. 79). Jest On najwyższym i definitywnym objawieniem Boga. Znajdując się $\mathrm{w}$ stanie definitywnego spełnienia, jest dla nas wzorem, a także źródłem inspiracji, nosicielem zbawienia, życia, wolności, miłości, synostwa Bożego; tym samym dokonuje nasze spełnienie się (DH s. 80).

O swej chrystologii mówi Schoonenberg, że może być nazwana chrystologią końcowego spełnienia człowieczeństwa (DH s. 80). „Dogmat chrystologiczny przedstawia się naszym oczom jako przekaz wiary $w$ jedyne, definitywne znaczenie Jezusa w porządku zbawienia. Jezus jest Słowem Boga ostatecznym i doskonałym. On jest wyzwalającym aktem Bożym, podjętym ze względu na nas; w Nim Bóg jest obecny obecnością wyzwalającą w sposób, który przewyższa wszelką działalność zbawczą, rozwiniętą przedtem przez Niego i zajmującą odtąd w historii miejsce definitywnego początku. To twierdzenie nie dotyczy jedynie tylko Pana uwielbionego, lecz także Jezusa w Jego ziemskim życiu i w Jego początku" (DH s. 57). W powyższym sensie trzeba rozumieć nie dość jasne i jednoznaczne swoiste ,wyznanie wiary" Pieta Schoonenberga (DH s. 218):

Wierzę [...]rw Jezusa, Sługę Bożego, kłóry przyszedł do nas w pelności Boga i w którym cała pełnia Boga mieszka cieleśnie; który pracował dla naszego uleczenia; który zerwał bariery ludzkie i wypowiedział słowa życia wiecznego; który dlatego został odrzucony, lecz cierpiał dla naszego wyzwolenia i umarł na krzyżu; który został wskrzeszony przez Boga, aby żyć i stanąć w sercu przyiszłości przyrzeczonej całemu stworzeniu.

\section{$\mathrm{V}$}

Tak wyglądają główne rysy koncepcji chrystologicznej sławnego teologa holenderskiego. Nie jest zadaniem niniejszego artykułu przeprowadzenie szczegółowej analizy jego argumentacji oraz ocena tej koncepcji ${ }^{4}$.

4 Omówienia i oceny poglądów Schoonenberga podjęli się liczni uczeni teologowie. Oto kilka tytułów takich studiów krytycznych: J. C o p pens, La personne de Jésus Christ. A propos d'un essai d'explication nouvelle, „Ephemerides' Theolo- 
Chciałbym jedynie na koniec wyrazić kilka uwag natury ogólniejszej na ten temat.

Schoonenberg reinterpretując definicję Soboru Chalcedońskiego, usiłuje wyjaśnić tajemnicę Jezusa Chrystusa w taki sposób, aby stała się ona bardziej zrozumiała i dostępna dla mentalności współczesnych chrześcijan, pozostających pod presją dążności sekularyzacyjnych i ateizujących. Ten chwalebny zamiar stara się on realizować w pewnej zależności od przesłanek nowoczesnej filozofii egzystencjalnej oraz od poglądów takich autorów jak J. Robinson, H. Küng, K. Rahner i N. Lohfing. Opinie ich są podzielone przez Schoonenberga w niektórych ważnych kwestiach. Widać to dość wyraźnie już w jego stanowisku w sprawie pojęcia dogmatu oraz zasad i natury interpretacji orzeczeń dogmatycznych, np. $\mathrm{w}$ twierdzeniu, że orzeczenie dogmatyczne ma tylko charakter modelu pouczenia o danych sprawach wiary dla obrony jej przed herezją, albo że „,prawdziwa interpretacja orzeczeń kościelnych jest planowym i twórczym nadawaniem sensu określonym tekstom"; lub też że w dzisiejszej sytuacji społeczno-kulturowej tłumaczenie dogmatów ,,jest zawsze w pewnym określonym stopniu tłumaczeniem na myślenie sekularyzacyjne". Widoczny jest wplyw H. Künga i częściowo N. Lohfinga, gdy chodzi o stanowisko w kwestii nieomylności czy bezbłędności orzeczeń dogmatycznych. Miałaby to być, jak widzieliśmy, nieomylność tylko ograniczona i względna, ,sama w sobie omylna, wobec tego, że sprawca jej Duch Swięty „prowadzi Kościół przez poszukiwania i próby, a stąd przez właściwe poglądy, przez całe i połowiczne prawdy i dlatego też przez połowiczne i całkowite błędy".

Niemniej wyraźny wpływ Robinsona czy Künga widać (1) w kwestionowaniu osobowego charakteru preegzystującego słowa Bożego oraz w przyjęciu przez Nie przy Wcieleniu natury ludzkiej Jezusa do swego uczestnictwa (enhipostaza), (2) w przyjmowaniu osoby ludzkiej Jezusa Chrystusa, (3) w przyznawaniu Mu ludzkiej transcendencji w stosunku do innych ludzi.

Chrystologia Schoonenberga słusznie nazwana jest „nową”. Odbiega ona bowiem dalece $w$ swych istotnych elementach od przyjętej od wieków tradycyjnej nauki Magisterium oraz odwiecznej wiary całego Kościoła katolickiego. Stanowi ona właściwie nową, zmodyfikowaną

gicae Lovamiemses" 45 (19619) s. 127-137; A. van Ro y, Contemporary christological questions, "Louvain Studie" 1968 s. 158-169; J. G a 1 ot, Vers une nouvelle christologie, Duculot-Lethiellaux 1971, s. 23-40; tenże, Tentativi di una nuova cristologia, "Civita Cathollica" 121 (1970) s. 484-494 L. R -vous que je suis? La christologie de P.J.A.M. Schoonenberg, "Nouvelle Revue Théologique" $2 / 5$ (197/2) 's. 11137-111411; K. R e in harld't, Die menschliche Transzendenz Jesu Christi. Zu Schoonenbergs Versuch einer nicht-chalkedonischer Christologie, ,Theologisches Jahrbuch" 1974 s. 212-226; A. Sk ow r o n ek, Chrystologia Pieta Schoonenberga, ,Sląskie Studia Historyczno-Teologiczne” 8 (1975) s. $431-52$. 
wersję odrzuconego już w starożytności przez Kościół arianizmu i adopcjanizmu. Główne zastrzeżenia budzi teoria enhipostazy natury boskiej w osobie ludzkiej Jezusa Chrystusa, zaprzeczanie Wcielenia osobowego Słowa Bożego oraz hipoteza tak zwanej ludzkiej transcendencji Jezusa Chrystusa. Istotne tezy koncepcji Schoonenbergowej mają mieć rzekomo podstawę $w$ tekstach Nowego Testamentu. Rzecz jednak w tym, że teksty te interpretuje nasz autor wprawdzie twórczo, lecz jednocześnie dość dowolnie, nadając im sens dostosowany sztucznie do jego koncepcji.

Nic dziwnego zatem, że do koncepcji Schoonenberga odniosła Kongregacja Doktryny Wiary negatywną ocenę (tecto nomine auctoris) w deklaracji z 22 lutego 1972 roku. Po przytoczeniu orzeczeń soborowych (Konstantynopolitańskiego I, Chalcedońskiego, Laterańskiego IV i Watykańskiego II) dokument Kongregacji stwierdzał, że wierze Kościoła „przeciwstawiają się te opinie, według których należy odrzucić pojęcie jednej osoby w Jezusie Chrystusie, zrodzonej według Bożej natury przez Ojca przed wiekami, a według natury ludzkiej w czasie z Maryi Dziewicy, i to twierdzenie, że człowieczeństwo Jezusa istnieje nie jako przyjęte przez przedwieczną osobę Syna Bożego, lecz raczej samo w sobie, jako osoba ludzka. Stąd tajemnica Jezusa Chrystusa polegałaby na tym, że Bóg objawiając siebie, byłby obecny w osobie Jezusa w najpełniejszy sposób. Ci, którzy sądzą w ten sposób, pozostają daleko od prawdziwej wiary w Chrystusa nawet wtedy, jeśli dodają, że można Jezusa uważać za Boga w tym sensie, iż Bóg w sposób najpełniejszy jest obecny w ludzkiej - jak mówią — osobie Jezusa" ${ }^{5}$.

ESQUISSE DE LA CHRISTOLOGIE DE PIET SCHOONENBERG

\section{R é s u m é}

On présente le projet d'une non-calcédoine christologie de P. S choonen$\mathrm{b}$ e $\mathrm{r} \mathrm{g}$ en contexte de sa vision de la réinterprétation des dogmes à partir, surtout de ses oeuvres: Il est Dieu des hommes et Geschichtlichkeit und Interpretation des Dogmas.

5 Acta Apostolicae Sedis 61 (1972) s. 2317-241. 